\title{
Biology, morphology and taxonomy of Lesser Date Moth, Batrachedra amydraula (Lepidoptera: Batrachedridae) under two different temperatures
}

\author{
Faheem Ahmed Jatoi ${ }^{1}$, Hakim Ali Sahito ${ }^{1,2^{*}}$, Tasneem Kousar ${ }^{1}$, Wali \\ Muhammad Mangrio ${ }^{1}$ and Zafar Hussain Shah ${ }^{1}$ \\ 1. Department of Zoology, Faculty of Natural Sciences, SALU-Khairpur-Pakistan \\ 2. Date Palm Research Institute (DPRI), Shah Abdul Latif University, Khairpur-Pakistan \\ *Corresponding author's email: hakim.sahito@salu.edu.pk \\ Citation \\ Faheem Ahmed Jatoi, Hakim Ali Sahito, Tasneem Kousar, Wali Muhammad Mangrio and Zafar Hussain Shah. \\ Biology, morphology and taxonomy of Lesser Date Moth, Batrachedra amydraula (Lepidoptera: \\ Batrachedridae) under two different temperatures. Pure and Applied Biology. Vol. 9, Issue 1, pp1137-1147. \\ http://dx.doi.org/10.19045/bspab.2020.90119
}

\begin{tabular}{|c|c|c|c|}
\hline Received: $12 / 10 / 2019$ & Revised: 31/12/2019 & Accepted: 02/01/2020 & Online First: 30/01/2020 \\
\hline
\end{tabular}

\section{Abstract}

The research study was conducted during the summer season and work methodology was based on 5 treatments and 5 replications under corridor room temperature and air-conditioner from egg to adult at DPRI, SALU-Khaipur. The overall mean population of eggs laid (45.4) with eggs fertility $(78.83 \%)$. The $1^{\text {st }}$ stage instar took $(2.78 \pm 0.30), 2^{\text {nd }}(4.58 \pm 0.41), 3^{\text {rd }}$ $(4.02 \pm 0.33), 4^{\text {th }}(5.48 \pm 0.41)$ and $5^{\text {th }}(7.54 \pm 0.32)$ days, pupae $(10.56)$ and total developmental days were (38.44). Thus; an adult male longevity (9.24) days and female was (11.00) besides; the total life span of male was observed (47.72) and female (49.61) days under corridor / natural room temperature. Thus; in air-condition room temperature, the first instar stage took (3.84 \pm 0.41$)$, second $(5.80 \pm 0.41)$, third $(5.06 \pm 0.42)$, fourth $(6.60 \pm 0.30)$ and fifth $(7.86 \pm 0.64)$ with overall mean (27.00) days. The pupae took (11.26), with developmental (38.26) days and the adult male longevity (4.70) and female (8.38) days. The life span of male (45.6) and female was also observed (46.64) days. The minimum egg population laid by a female as compared to corridor room temperature with an overall mean population of fecundity was (15.33) female and fertility (83.14)\%. The specimens were separated for proper male and female identification for all morphology and taxonomic characteristics. The sex ratio was found quite same in both temperatures but found fluctuation of day's consumption in the life cycle. Body length and width measured in micrometers but larvae in millimetres. It is further recommended that the larval stages were the most voracious feeder at that times the management techniques.

Keywords: Biology; Fecundity; Fertility; Life span; LDM; SEX ratio

\section{Introduction}

Dates fruit is gifted fruit by God, used for the formation of many industrial products including; sweets, chocolates, salads, breakfast cereals, sauces, variety of dishes, backing, and confectionery products [1]. This major crop is the oldest domesticated for 700 years to up to date in Middle East 
[2]. More than three hundred varieties of date palm have been cultivated and documented in Pakistan. These varieties consisted genetic divergence and change in their biochemical and morphological appearance [3].

The origin of the date palm is not well known but little documentation suggests their origin from Western India and Mesopotamia [4], and nowadays about more than five thousand varieties of date palm being cultivated in thirty-seven countries of the world [5]. Tunisia, Egypt, Libya, Saudi Arabia, Oman, Iran, Sudan, United Arab Emirates, Algeria, and Pakistan are top date palm producing countries [6]. When there is crowding of trees, mixed cultivars plantation, unproductive trees, seedling, poor drainage, accumulation of salt, tillage or fertilization, insufficient irrigation, lack of disease control and pest control condition of other weeds and crops, water scarcity and soil degradation rely the negative effect on date palm production [7]. Tree litters, weeds, shrubs surround the tree are supportive in response to the increase of insect population. An effective program of integrated pest management and general awareness are the sufficient tool to save date palm orchards and their fruits, weeds surround the trees Shrubs, tree litter favored increased the population of insects [1].

The Date palms (Phoenix dactylifera L.) severely damaged by several other pests and mites but Lesser date moth, Batrachedra amydraula. These insect pests harm the date orchards in many countries of the world including; Oman, United Arab Emirates, Israel, Libya, Iran, Egypt, Saudi Arabia, Bahrain, Qatar, Iraq, North Africa, India, Pakistan, Iran, Tunisia, Libya, Egypt and most countries of the Middle East $[8,9]$. These pests also hit the ripen fruits and after the entrance of the pest outer layer of the fruit became radish- brown and dry and infected fruits either become shrink and form bunch like structure or fallen on the surface of the ground [10]. Fruits in throughout the world are infected by several insect pests but date palm orchards and their fruits are facing certain problems in respect of production because these fruits are damaged by mites, Oryctes rhinoceros, Batrachedra amydraula, Arenipses saabella, lesser date moth, Oli, and Rhynchophorus ferrugineus but $B$. amydranla widely attack cause seventy percent crops loss [11].

The eggs of this pest are light yellow, smaller in size, on the surface of the immature fruits and flowers they commonly lay their eggs, their pupae are brown-light colored, long and slender shaped [1]. Larvae may feed more than third portion of fruit after that larvae left the first and enter into neighbouring fruit but during their whole lifetime larvae hits three to four fruits. Just before the ripening larvae attack then left the fruit by leaving like debris [12]. The maximum attack occurred in dropped fruits as compared to the intact fruits and from the dropped fruits insects move to the bunches of the fruits, easily moving one fruit to neighboring. Their larvae take the nourishment on new growing inflorescences through entering at the end region of calyx [13]. The main theme of present works to aware the local growers of this area and due to lack of knowledge about $B$. amydraula date fruits are severely damaged annually and dates growers are facing gradually economical losses. It is strictly needed to manage certain strategies and control measures to overcome from the harmful effects of this pest.

\section{Material and methods \\ Culture maintenance under laboratory conditions at DPRI, SALU-Khairpur}

The damaged containing lesser date moth were captured from date palm orchards at district Khairpur and brought in Date Palm Research Institute (DPRI), Shah Abdul Latif University, Khairpur to observe the biology, morphology and taxonomy parameters under two different temperatures during, 2018. In this regard, the five treatments were kept and 
replicated 5 times for summer seasons. The collection of lesser date moth was taken from Aseel date palm variety which is the most prominent variety in our agroecosystem. The infected dates were kept under natural occurred corridor temperature at $30 \pm 2^{\circ} \mathrm{C}$ and $65 \pm 5 \%$ (R.H.) and photoperiod of 14:10 (L: D) as light and dark in a constant room or corridor temperature during in summer cropping season. At that time, the second experiment was carried out in air condition room temperature $20 \pm 2^{\circ} \mathrm{C}$ and $45 \pm 5 \%$ (R.H). Temperature and relative humidity were checked through the digital hygrometer kept under Laboratory conditions. All stages of lesser date moth such as; egg, larvae, pupae, and an adult were taken through the infested fruits and visually captured from the orchards, those were reared as a maintained culture at laboratory conditions. For morphotaxonomic characteristics of the pest support of digital camera Lucida was taken for better measurement and identification.

\section{Biology study of Lasser date palm under laboratory conditions}

Before the biological study, adults of lesser date moths were separated proper confirmation of male and female. Latter on; an alive pair of lesser date moth (female and male) were transferred into plastic jars $(10 \mathrm{~kg})$ containing dry dates for mating and egg-laying process. Thus; an artificial diet (drops of honey adhered on stick and glucose absorbed in a cotton swab) were provided to adults and copulating time and behavior were checked and counted. When the eggs were laid, those were counted through magnifier glass finally; time duration of eggs laid, up to hatching were counted. In this continuous phase, all stages were observed with their time duration. Photography was taken by CPU connected camera and external body organs were measured $\mu \mathrm{m}$, respectively.

The eggs laid on dry dates were separated and kept into glass Petri dishes containing (6cm diameter). The newly hatched larvae of lesser date moth were provided fresh food semi-dry dates immature fruits. But during the off-season, the dry dates were provided on an alternate day up to the completion of the larval stage to the conversion into pupae. The pupae release a yellow silk cocoon around its body, at this stage food is not given due to inactive feeding behavior. After an adult emergence; the sex ratio ( $\delta$ : $ᄋ$ ) was also observed and described as in under given tables of both temperatures.

\section{Morphology of Lasser date palm under laboratory conditions}

After the biological study, the adults of lesser date moths were anesthetized with alcohol and the specimens were separated based on morphological characteristics for proper male and female identification under laboratory conditions. Having separated all stages from egg to adult was thoroughly examined through the help of a microscope and mounted for species identifications.

\section{Taxonomy of Lasser date palm under laboratory conditions}

On the basis of taxonomic status such as; measurement of all stages larvae as; $1^{\text {st }}$, $2^{\text {nd }}, 3^{\text {rd }}, 4^{\text {th }}$, and $5^{\text {th }}$ were taken in millimetres $(\mathrm{mm})$, body length of male and female, length and width of paired wings, length of antennae, anterior, median, posterior pairs of legs, male and female eyes length and width, length of thorax, abdominal region, head length and width, size of pre-pupae and pupae were taken in $\mu \mathrm{m}$. The taxonomic research study was initiated with the help of a digital microscope under laboratory conditions whereas; the photography was done through the help of camera inter-connected with micro-scope at Date Palm Research, Institute, SALU- Khairpur.

\section{Statistical analysis}

The data put into Excel spreadsheets and finally, the analysis of variance (ANOVA) and compare of means was performed through statistical package SXW, USA version, 8.1.

\section{Results}


The results of biology studies of lesser date moth on date palm fruits at the time of the first attack at different orchards were carried out throughout the season on temperature $30 \pm 2^{\circ} \mathrm{C}$. When it was observed that the raw fruits of dates were infected, those were collected and culture maintained for rearing the pest under laboratory conditions. For this purpose, the research work was performed from the egg to adult of the pest on five treatments which were replicated five times.

The eggs laid by a female in different treatments were counted in singly on a daily basis. The maximum population of eggs laid by female was in T4 (50.6) and minimum in T5 (39.2) and overall mean population fecundity was (45.4) the maximum fertility of eggs were in $\mathrm{T} 2$ (81.65) \% and minimum in T4 (69.82) and overall mean percent population was observed (78.83). The maximum incubation period was in T1 (5.2) and minimum in T4 (4.0) days with an overall mean population (4.64) days.

The first instar consumed $(2.78 \pm 0.30)$, second (4.58 \pm 0.41$)$, third $(4.02 \pm 0.33)$, fourth $(5.48 \pm 0.41)$ and fifth $(7.54 \pm 0.32)$ days as shown in (Fig. 1). The statistically analysis shows the significant difference among the all days consumed by larval stages of lesser date moth $(\mathrm{DF}=4,4 ; \mathrm{F}=$ 28.47; $\mathrm{P}=0.000$ ) under corridor temperature $30 \pm 2{ }^{\circ} \mathrm{C}$ at DPRI, during the summer season, 2018. The maximum overall days taken by $\mathrm{T} 1$ (25) and minimum in T3 (19) with the overall mean of (22.80), respectively. The maximum mean of pupae stage consumed days in T5 (11.8) and minimum in T1 (9.6) with the overall mean (10.56) with the developmental days were in T5 (40.8) and T2 / T4 (37.0) with the overall mean (38.44) days, respectively. Thus; the maximum longevity of female was observed in $\mathrm{T} 1$ (12.2) and minimum in T4 (10.2) with the overall mean of (11.00) with the male in T1 (10.2) and T5 (7.6) with the overall mean of adult longevity (9.24) besides; the life span of female was observed in T1 (51.4) and T2 (48) with the overall mean (49.61). The maximum life span in male was observed in $\mathrm{T} 1$ (50.2) and minimum in T2 (46) with the overall mean (47.72) days whereas; the sex ratio with the maximum population was observed in T2, T3 / T5 (1:2) and minimum in $\mathrm{T} 1 / \mathrm{T} 4$ (1:1) with the overall mean sex ratio of male and female $(\hat{O}:$; $)$ were observed such as; 1.2 and 1.4 in corridor natural temperature under laboratory conditions, respectively (table $1)$.

The research study was conducted on the biology of $B$. amydraula on $P$. dactylifera. In this study, that data was taken on all stages of the pest. Which was reared on raw dates collected by near date palm cultivated at date palm research institute on temperature $20 \pm 2^{\circ} \mathrm{C}$ and $45 \pm 5 \%$ (R.H.) The temperature was maintained through air-conditioner installed at laboratory conditions. It was observed that, there were minimum population of eggs laid by female as compared to corridor room temperature but it was found with maximum population in T3 (19.4) and minimum in T2 (16.5) with the overall mean population of fecundity was (15.33) / female with the maximum fertility of eggs were in T2 (95.15) \% and minimum in T3 (73.19) with the overall mean percent population was observed (83.14). Thus; the maximum incubation period was in $\mathrm{T} 1$ (5.1) and minimum in T2 (3.3) days with overall mean population (4.50) days.

During the larval stages, the $1^{\text {st }}$ instar took $(3.84 \pm 0.41), \quad 2^{\text {nd }} \quad(5.80 \pm 0.41), \quad 3^{\text {rd }}$ $(5.06 \pm 0.42), \quad 4^{\text {th }}(6.60 \pm 0.30)$ and $5^{\text {th }}$ (7.86 \pm 0.64$)$ days. The statistically analysis shows the significant difference among the all days consumed by larval stages of lesser date moth $(\mathrm{DF}=4,4 ; \mathrm{F}=15.97 ; \mathrm{P}=$ 0.000) under air-conditioning controlled temperature $20 \pm 2^{\circ} \mathrm{C}$ which is further described in groups under given table 2 .

Whereas; the maximum overall days taken by $\mathrm{T} 1$ (30) and minimum in T3 (23) with the overall mean of (27.00). Hence; the maximum mean of pupae stage took in T3 
(12.6) and minimum in T1 (9.8) with the overall mean (11.26) with the developmental days in T1 (39.8) and T3 (35.6) with the overall mean (38.26) days, respectively. The female with maximum days was observed in T1 / T4 (9.8) and minimum in T5 (6.6) with the overall mean of (8.38) with the male in T2 (7.2) and T4 (3.3) with the overall mean of adult longevity (4.70), respectively. The life span of females was observed in T1 (49.6) and T3 (43.1) with the overall mean (46.64) Thus, the maximum life span in males was observed in $\mathrm{T} 2$ (45.6) and minimum in T3 (40.4) with the overall mean (42.95). The sex ratio with the maximum population was observed in $\mathrm{T} 1$, T3 / T4 (1:2) and minimum in T2 / T5 (1:1) with the overall mean sex ratio of males and females $\left(\delta^{\lambda}:\right.$ ㅇ) were observed 1.00 and 1.60 , respectively (table 2 ).

The morphology eggs light yellow and oval in shape. All five stages larvae found light yellow in color but $1^{\text {st }}$ stage larvae found more elongated than the next stages and $4^{\text {th }}$ and $5^{\text {th }}$ larvae found a thicker light yellow that enlarging body structure. Prepupae much darker and anteriorly contain blackish pigmentation found curved in shape and nearly pointed at posterior extremity. Pupae contain puffy hairs above the covering and found in half white in coloration. Finally, adults of males and females were found with pigmentation dirty in colors whereas; the body structure and abdominal thickness distinguish between the male and female of this pest (Fig. 1).

The total length of adult males recorded 1614.32 in length and maximum width at the mid-region that consists 458. 04 in micrometers and females recorded 15 26.14 with $422.04 \mu \mathrm{m}$. Male wings comprise 1012.16 in length 244. 06 in width, female wings consist 998.26 in length and 213.09 in width. A paired antenna of male was measuring 195.43 and female 122.33 in length. Anterior pair of legs of the male consists 1552. 34, female pair 1426.25, middle pair of male legs measured 2645.27, female 2498.34 and posterior pair of male legs measuring 1645.56 and female 1546.56 in length. Male eyes in length 56.08 in length 45.40 in width and female 51.06 in length and 42.26 in width. Thorax of male comprised 266.73 in length and 125.12 in width, female thorax 246.58 in length and 38.21 in size. Abdominal region of male consists 874.68 in length and 235.80 in size, female comprises 811.13 in length and female consist 216.68 in size. The head region of males measuring 434.89 and female 413.16 was observed in size whereas; larval measurements were taken in millimetres. The $1^{\text {st }}$ stage larvae of male consist $0.9 \mathrm{~mm}, 2^{\text {nd }}$ stage $1.4,3^{\text {rd }}$ stage 1.9 , $4^{\text {th }} 1.6$ and $5^{\text {th }} 1.2$ in size while; female larvae consists at $1^{\text {st }} 0.8 \mathrm{~mm}, 2^{\text {nd }} 1.2,3^{\text {rd }}$ $1.5,4^{\text {th }} 0.9$ and $5^{\text {th }} 0.8$ in size. The size of pre-pupae of male measures $0.8 \mathrm{~mm}$ and female $0.6 \mathrm{~mm}$ and pupae size of the male consists of 0.7 in size and females measuring $0.5 \mathrm{~mm}$, respectively. Further, the photography of all stages under laboratory conditions at Date Palm Research Institute, Shah Abdul Latif University, Khairpur are given as under:

\section{Discussion}

The Khairpur district is a prominent date palm growing in Sindh. "Aseel" variety is considered as unique for their taste and yield production and it is the high priced item of the markets. About $34 \%$ of date's fruits only share Khairpur and Sindh overall share $83.33 \%$. This district provides an economic source to thousands of families and labour force who come every year to earn money for their livelihood. In Pakistan arid region is considered as friendly regions for date grow.

Today's dates are widely used in industries and it is an indication that future of this fruit is bright. In Sindh cultivation area is 29,300 and all over the Pakistan 84,700, respectively gives 201,100 and 426,300 tones [14]. $P$. dactylifera is oldest fruit [15], considered as major crop of Africa and Asia [16]. It grows well under arid and 
semi-arid climatic conditions than other fruit crops [17]. The cultivation of dates in Egypt having oldest history like; the history of Islam but Spain is the first country from which dates extended to the South Asia, Arabian Peninsula, Middle East, and North Africa [18]. Arab countries giving more than $67 \%$ date yields throughout the world [19].

$P$. amydraula is the key pest of date fruits [12]. These pests lay the eggs on the surface of leaves his larvae harm green and ripening stage of date orchards, the present result is with the agreement of [20]. In Middle Eastern countries i-e; Libya, Iran, Tunisia, Iraq, Egypt, Saudi Arabia, Yemen, Bahrain, most of the African countries including Asia present date palm pest is widely distributed and cause $75 \%$ losses [21]. Here, we have conducted research study to check out the biology parameters like described [13].

The biological characteristic of $B$. amydrula is reported with the agreement of [22], and described that the eggs of these pests are smaller in size and yellowish in color. Larvae duration and conversion into pupae resemble the work of [23], Larvae from silt like appearance and enter inside the fruit when fruit became infected it forms dark appearance and within 28 days fall on the ground. $B$. amydrula hits fruits at an early period some time there damage may reach up to $100 \%$ [24]. This pest is generally known as $1^{\text {st }}$ harvested pest. This pest started infestation flu from the date's orchards and then transmitted towards the storage dates and severely damage many storage stored varieties [25]. In one year two-generations can be produced for this pest and also for another pest of dates [26, 27]. The morphology and taxonomy characterize were also studied under the laboratory conditions which found totally different from each other from egg, larvae, pupae and adult stages of male and female in length and width with the pigmentation. Morphological characteristics of the present pest are in agreement with the [1] who described the external coloration of the pest from egg to adult and taxonomic status compared with the work of [17] who documented taxonomic position of $B$. amydrula and their severe effects on date fruits. The date palm plantation increasing for few decades that severely attached by lesser date moth pest at the tropical upper region of Sindh. 
Table 1. Biology of Lesser date moth under corridor temperature $30 \pm 2^{\circ} \mathrm{C}$ at DPRI, during the summer season, 2018

\begin{tabular}{|c|c|c|c|c|c|c|c|c|c|c|c|c|c|c|c|c|c|c|}
\hline \multirow[b]{2}{*}{ Trt. } & \multirow{2}{*}{$\begin{array}{c}\text { Eggs laid } \\
/ \\
\text { Fecundity }\end{array}$} & \multicolumn{2}{|c|}{ Fertility } & \multirow{2}{*}{$\begin{array}{c}\text { Incubation } \\
\text { period } \\
\text { (days) }\end{array}$} & \multicolumn{6}{|c|}{ Larval stages in days } & \multirow{2}{*}{$\begin{array}{l}\text { Pupae } \\
\text { in } \\
\text { days }\end{array}$} & \multirow[b]{2}{*}{$\begin{array}{l}\text { Development } \\
\text { in days }\end{array}$} & \multicolumn{2}{|c|}{$\begin{array}{c}\text { Adult } \\
\text { longevity }\end{array}$} & \multicolumn{2}{|c|}{ Life span } & \multicolumn{2}{|c|}{$\operatorname{Sex}$ ratio $(\delta: \uparrow)$} \\
\hline & & Mean & $\%$ & & $1^{\text {st }}$ & $2^{\text {nd }}$ & $3^{\text {rd }}$ & $4^{\text {th }}$ & $5^{\text {th }}$ & $\begin{array}{c}\text { Total } \\
\text { days } \\
\text { consumed }\end{array}$ & & & Male & Female & Male & Female & Male & Female \\
\hline $\mathrm{T}_{1}$ & 44.4 & 35.2 & 79.23 & 5.2 & 3.1 & 5.5 & 4.3 & 5.3 & 8.4 & 26.6 & 9.6 & 39.8 & 10.2 & 12.2 & 50.2 & 51.4 & 1.4 & 1.2 \\
\hline $\mathrm{T}_{2}$ & 45.2 & 37 & 81.65 & 5.0 & 2.4 & 3.2 & 5.0 & 6.8 & 7.3 & 24.7 & 10.2 & 37 & 9 & 11 & 46 & 48 & 1.2 & 2.1 \\
\hline $\mathrm{T}_{3}$ & 47.6 & 38.6 & 81.34 & 4.6 & 2.1 & 4.4 & 3.2 & 4.3 & 6.8 & 20.8 & 11.6 & 37.6 & 9.4 & 10.6 & 46.2 & 48.2 & 1.0 & 2.3 \\
\hline $\mathrm{T}_{4}$ & 50.6 & 35.4 & 69.82 & 4.0 & 2.5 & 5.3 & 4.2 & 5.2 & 8.2 & 25.4 & 9.6 & 37 & 10 & 10.2 & 47.8 & 48.4 & 1.3 & 1.2 \\
\hline $\mathrm{T}_{5}$ & 39.2 & 31.8 & 81.12 & 4.4 & 3.8 & 4.5 & 3.4 & 5.8 & 7.0 & 24.5 & 11.8 & 40.8 & 7.6 & 11 & 48.4 & 49.8 & 1.2 & 1.5 \\
\hline Mean & 45.4 & 35.6 & 78.83 & 4.64 & $\begin{array}{l}2.78 \pm \\
0.30^{d}\end{array}$ & $\begin{array}{l}4.58 \pm \\
0.41^{\mathrm{bc}}\end{array}$ & $\begin{array}{l}4.02 \pm \\
0.33^{c}\end{array}$ & $\begin{array}{l}5.48 \pm \\
0.41^{b}\end{array}$ & $\begin{array}{l}7.54 \pm \\
0.32^{\mathrm{a}}\end{array}$ & $\begin{array}{c}24.4 \pm \\
0.97\end{array}$ & 10.56 & 38.44 & 9.24 & 11 & 47.72 & 49.16 & 1.2 & 1.4 \\
\hline
\end{tabular}

Table 2. Biology of Lesser date moth under air-conditioning controlled the temperature $20 \pm 2{ }^{\circ} \mathrm{C}$ at DPRI, SALU - Khairpur

\begin{tabular}{|c|c|c|c|c|c|c|c|c|c|c|c|c|c|c|c|c|c|c|}
\hline \multirow[b]{2}{*}{ Trt. } & \multirow{2}{*}{$\begin{array}{l}\text { Eggs laid } \\
/ / \\
\text { Fecundity }\end{array}$} & \multicolumn{2}{|c|}{ Fertility } & \multirow{2}{*}{$\begin{array}{l}\text { Incubation } \\
\text { period } \\
\text { (days) }\end{array}$} & \multicolumn{6}{|c|}{ Larval period in days } & \multirow{2}{*}{$\begin{array}{l}\text { Pupae } \\
\text { in } \\
\text { days }\end{array}$} & \multirow[b]{2}{*}{$\begin{array}{l}\text { Development } \\
\text { in days }\end{array}$} & \multicolumn{2}{|c|}{$\begin{array}{c}\text { Adult } \\
\text { longevity }\end{array}$} & \multicolumn{2}{|c|}{ Life span } & \multicolumn{2}{|c|}{ Sex ratio $\left.(\jmath:+)^{\lambda}\right)$} \\
\hline & & Mean & $\%$ & & $\mathbf{1}^{\text {st }}$ & $2^{\text {nd }}$ & $3^{\text {rd }}$ & $4^{\text {th }}$ & $5^{\text {th }}$ & $\begin{array}{c}\text { Total } \\
\text { days } \\
\text { consumed }\end{array}$ & & & Male & Female & Male & Female & Male & Female \\
\hline $\mathrm{T}_{1}$ & 17.8 & 13.4 & 75.28 & 5.1 & 4.8 & 6.8 & 5.5 & 6.5 & 9.8 & 30 & 9.8 & 39.8 & 3.4 & 9.8 & 43.2 & 49.6 & 1.6 & 2.4 \\
\hline $\mathrm{T}_{2}$ & 16.5 & 15.7 & 95.15 & 3.3 & 3.1 & 4.6 & 6.2 & 7.0 & 7.0 & 27 & 11.4 & 38.4 & 7.2 & 8.2 & 45.6 & 46.6 & 1.2 & 1.1 \\
\hline $\mathrm{T}_{3}$ & 19.4 & 14.2 & 73.19 & 5.1 & 3.2 & 5.2 & 4.0 & 5.8 & 6.2 & 23 & 12.6 & 35.6 & 4.8 & 7.5 & 40.4 & 43.1 & 1.7 & 2.5 \\
\hline $\mathrm{T}_{4}$ & 16.7 & 14.8 & 88.62 & 4.5 & 3.2 & 6.6 & 5.4 & 6.2 & 8.8 & 28 & 10.2 & 38.2 & 3.3 & 9.8 & 41.5 & 48 & 1.6 & 2.6 \\
\hline $\mathrm{T}_{5}$ & 11.5 & 9.6 & 83.47 & 3.8 & 4.9 & 5.8 & 4.2 & 7.5 & 7.5 & 27 & 12.3 & 39.3 & 4.8 & 6.6 & 44.1 & 45.9 & 1.1 & 1.2 \\
\hline Mean & 15.33 & 13.54 & 83.14 & 4.5 & $\begin{array}{l}\text { 3.84 } \pm \\
0.41^{\mathrm{d}}\end{array}$ & \begin{tabular}{|l|}
$5.80 \pm$ \\
$0.41^{\text {bc }}$
\end{tabular} & $\begin{array}{l}5.06 \pm \\
0.42^{\mathrm{c}} \\
\end{array}$ & $\begin{array}{l}6.60 \pm \\
0.30^{b} \\
\end{array}$ & $\begin{array}{l}7.86 \pm \\
0.64^{\mathrm{a}} \\
\end{array}$ & $\begin{array}{c}29.16 \pm \\
1.48 \\
\end{array}$ & 11.26 & 38.26 & 4.7 & 8.38 & 42.96 & 46.64 & 1.0 & 1.6 \\
\hline
\end{tabular}


Jatoi et al.

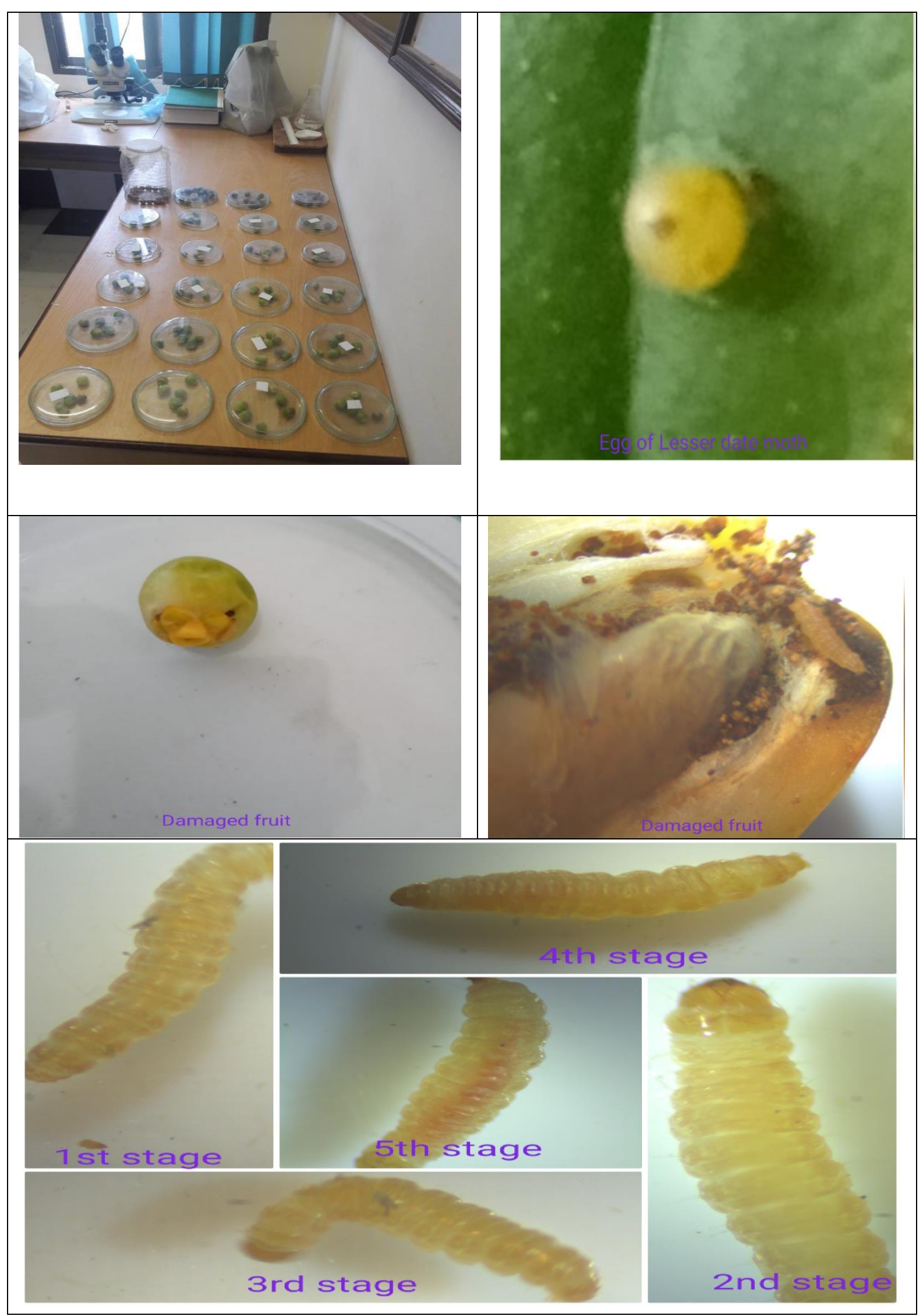




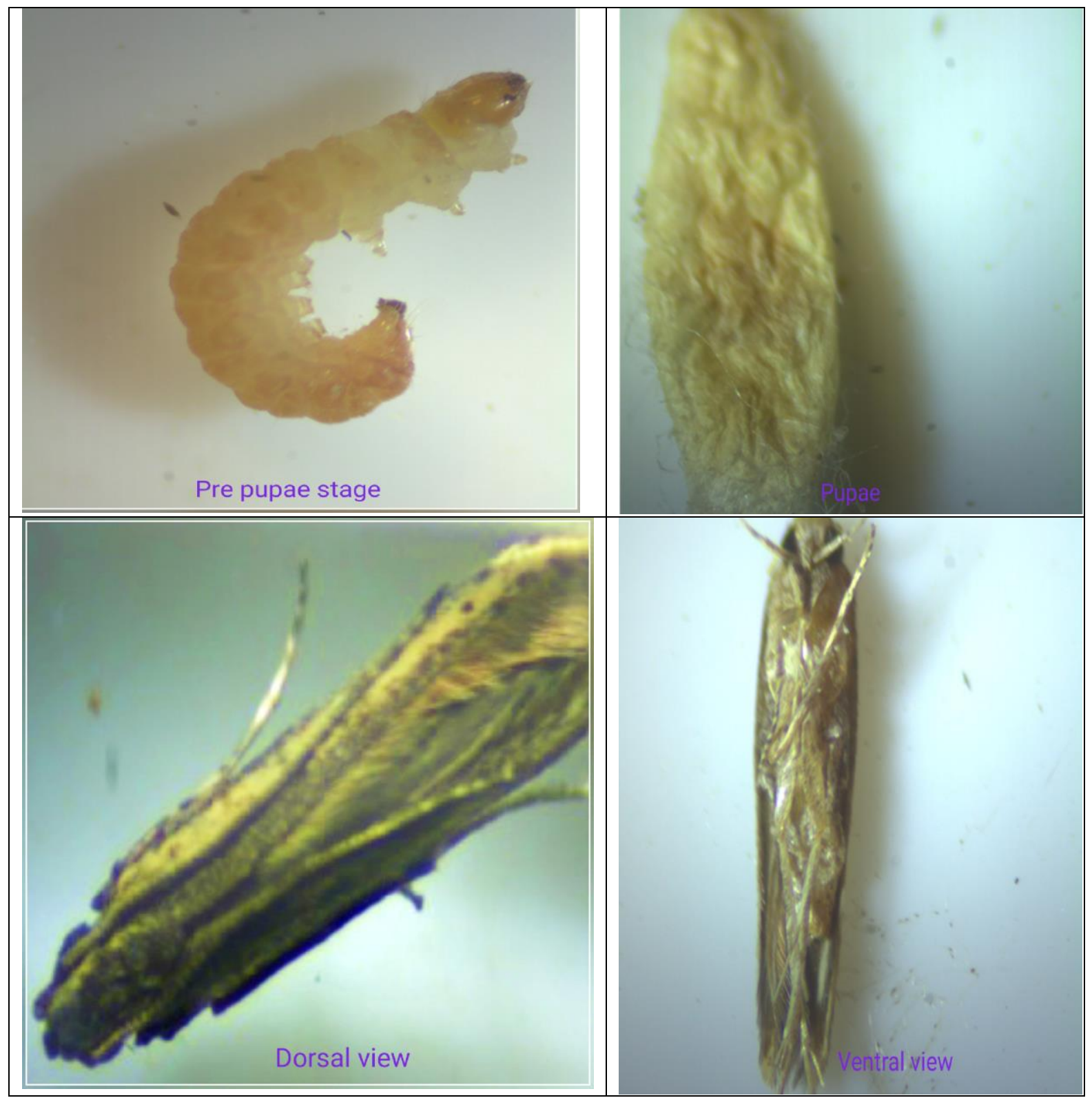

Figure 1. Photo gallery of different life stages of Lesser date moth under laboratory conditions

\section{Conclusion and recommendations}

It is concluded that date crop is bumper crop of this region majority of local people of this area are engaged this crop and this crop is consider as source of their live hood. The importance of fruit is also described in many religious books. The Hakeem (Medicinist) used these fruits as a medicine and food source. Presently; it has been identified as the most useful and universally fruit used invaluable food items. Local people of this area cannot recognize present pest which is most harmful and cause great loss in yield production of dates because there is lack of awareness and unavailability of the resources. In this regard, it is urgent call to manage this pest by the application of certain control measures and enhance the quantity and quality of date fruits and earn economy. It could also be benefitted from this biological study in terms of timing by applying proper management to combat the $B$. amydraula population and prophylactic planning in this manner will 
be the best authentic tool in protection of fruits from severe losses.

The population dynamics when observed at date palm orchards located at Queen District, Khairpur - Sindh to establish biological research study of a pest during the season that is most suitable for the exploitation of biological control agents under the date palm field conditions and the bio-synthetic control measures when reasonably is needed. In this regard scholars take strictly attention to collect present pest and rear under laboratory conditions. Authors are in this response to establish all stages of the pest from egg to adult, taxonomy position and all morphological appearance for better understanding. This scientific documentary will be supportive tool to combat $B$. amydrula insect pests.

\section{Author's contributions}

Conceived and designated experiments: FA Jatoi \& HA Sahito. Experiments performed: FA Jatoi \& WM Mangrio: Data analyzed: HA Sahito \& T Kousar: Contributed analysis tools: ZH Shah \& FA Jatoi. Research article wrote: FA. Jatoi \& HA Sahito.

\section{Acknowledgment}

The researchers are highly thankful to the growers of $P$. dactylifera of the district: Khairpur for their co-operation and collection of infested fruits from their orchards and separating the different larval stages from the un-ripen fruits for the purpose in response of biological research study under laboratory conditions at Date Palm Research Institute (DPRI), SALUKhairpur.

\section{References}

1. Harhash M, Mourad A \& Hammad S (2003). Integrated crop management of the lesser date moth Batrachedra amydraula Meyr. (Lepidoptera: Cosmopteridae) infesting some datepalm varieties in Egypt. Comm in Agri and Appli Bio Sci 68: 209-221.

2. Flower JM, Hazzouri KM, GrossBalthzard M. Mo Z, Koutroumpa K \& Perrakis A Ferrand S, Khierallah HS,
Fuller DQ, Aberlenc F, Fournaraki C \& Purugganan MD (2019). Cross-species hybridization and the origin of North African date palms. PNAS 116(5): 1651-1658.

3. Markhand GS, Abul-Soad AA, Mirbahar AA \& Kanhar NA (2010). Fruit characterization of Pakistani dates. Pak J Bot 42(6): 3715- 3722.

4. Wrigley G (1995). Date Palm, Simmonds (eds.). Evolution of crop plants. 2nd ed. Longman Group Essex UK. In J Smartt and NW 399-403.

5. Akhtar W, Rasheed A, Shinwari ZK, Naqvi SMS \& Mahmood T (2014). Genetic characterization of different Pakistani date palm varieties. Pak J Bot 46(6): 2095-2100.

6. Kader AA \& Hussein AM (2009). Harvesting and Post-harvesting handling of dates. Inter Cent Agri Res Dry Areas (ICARDA).

7. Carpenter JB (1981). Improvement of traditional date culture. Date palm J 1: 1-16.

8. Latifian M \& Nejadian ES (2009). Study of the Lesser Moth Batrachedra amydraula (Lepidoptera: Batrachedridae) Distribution Based on Geostatistical Models in Khuzestan Province. Journal of Entomological Res 1(1): 43-55.

9. AL-Zadjali TS, Abdallah FF \& ELHaidari H (2006). Insect Pests Attacking Date Palms and Dates in Sultanate of Oman. Egyp J Agric Res 84(1): 51-9.

10. Latifian M (2012). The effects of cultural management on the lesser date moth (Batrachedra amydraula Myer) infestation. Emirates Journal of Food and Agriculture 24: 224-229.

11. Michael IF (1970). Economic importance and control of Batrachedra amydraula Meyr. (The lesser date moth) in the UAR. Date Grs Inst Rep 47: 9-10.

12. Perring TM, El-Shafie HAF \& Wakil W (2015). Carob Moth, Lesser Date Moth, and Raisin Moth. In: Wakil W, Faleiro 
JR, Miller TA (eds) Sustainable pest management in date palm: current status and emerging challenge. Springer-Verlag Berlin Heidelberg Germany 134-141.

13. Dowson VHW (1982). Date production and protection: with special reference to North Africa and the Near East. Food and Agriculture Organization of the United Nations, Rome, FAO. Plant production and protection paper 35: 1294.

14. Sayed (2006-07). Agric. Statistics of Pakistan. Govt of Pakistan, Ministry of Food, Agri. and Livest. (Econ. Wing) Islamabad. Plant Prod. \& Prot. Paper $156 \operatorname{Rev} 156$.

15. Zohary D \& Hopf M (2000). Domestication of palms in the old world: the origin and spread of cultivated plants in West Asia, Europe, and the Nile Valley. Oxford University press Oxon UK.

16. Zaid A \& Arias-Jimenez EJ (2002). Date Palm cultivation. Rome Italy. FAO Plant Production and Protection Paper 156 (Rev. 1).

17. Patankar HV, Al-Harrasi I Al-Yahyai R \& Yaish MW (2018). Identification of candidate genes involved in the salt tolerance of date palm (Phoenix dactyliferaL.) based on a yeast functional bioassay. DNA and Cell Biol.

18. Nixon RW (1951). The date palm: "Tree of Life" in the subtropical deserts. Econ Bot 5: 274-301.

19. Juhany LI (2010). Degradation of date palm trees and date production in Arab countries: causes and potential rehabilitation. Australian J of Basic and Appl Sci 4(8): 3998-4010.

20. Eitam A (2001) Oviposition behavior and development of immature stages of Parasierola swirskiana, a parasitoid of the lesser date moth Batrachedra amydraula. Phytoparasitica 29: 405412.
21. Howard FW, Moore D, Giblin-Davis RM \& Abad RG (2001). Insects on Palms. CABI Publishing, Wallingford, UK.

22. Shayesteh N, Marouf A \& Amir-Maafi M (2010). Some biological characteristics of the Batrachedra amydraula Meyrick (Lepidoptera: Batrachedridae) on main varieties of dry and semi-dry date palm of Iran. Proc of the 10th Inter Working Conf on Stored Product Protection Lisbon Portugal 151-155.

23. Levi-Zada A, Fefer D, Anshelevitch L, Litovsky A, Bengtsson M, Gindin G \& Soroker V (2011). Identification of the Sex Pheromone of the Lesser Date Moth, Batrachedra amydraula, Using Sequential SPME Auto-sampling. Tetrahedron Lett 52: 4550-3.

24. AL-Jorany RS \& AL-Delamy KA (2010b). Model Design to Estimate the Economic Threshold Level of Lesser Date Moth Batrachedra amydraula Meryick in the Central IRAQ. The Iraqi $J$ of Agric Sci 43(1): 85-91.

25. Gharib A (1968). Batrachedra amydraula Meyr (Super-family: Gelechoidea)-(Momphidae

(Cosmopterygidae)). Entomol et Phytopatol Appliqees 27: 63-67

26. Damghani R (1998). Biology, natural enemies and damage of generations of lesser date moth in Bam region. Final report of project No. 127-11-75-149. Iranian Research Institute of Plant Protection. Agricultural Research Extension and Education Organization.

27. Sahito HA, Mallah NA, Kousar T, Kubar WA, Shah ZH, Jatoi FA \& Mangrio WM (2017). Life table parameters of saw toothed grain beetle, Oryzaephilus surinamensis (L.1758) on different varieties of stored date palm fruits infested under laboratory conditions. J Entomol and Zool Stu 5(1): 95-99. 